\title{
Synthetic Seeds Production and Regeneration of Oxalis triangularis for Mass Propagation and Conservation
}

\author{
Rosna Mat Taha, Noraini Mahmad, Jamilah Syafawati Yaacob, Noorlidah Abdullah, and Sadegh \\ Mohajer
}

\begin{abstract}
Oxalis triangularis is an attractive ornamental plant propagated by using bulbs and has no natural viable seeds. It is an ideal decorative plant for growing in pots and other containers. The plant is not widely found in Malaysia and mostly obtained from Thailand. Hence, it is necessary to propagate this plant through tissue culture system for large scale production. In the present study, production of synthetic seeds was attempted from this species and the synthetic seeds managed to survive after 7 and 30 days after storage at $4^{\circ} \mathrm{C}$. The rate of synthetic seeds conversion to complete plants after 7 days was $96.67 \%$ with 4.57 mean shoot numbers, while after 30 days of storage, the conversion rate slightly decreased to $\mathbf{9 0 \%}$ with only 3.97 shoots formation per bead. The present work reports and discusses the potential of tissue culture technique as an alternative method for mass propagation and conservation of this interesting and attractive ornamental plant for future uses and exploitation.
\end{abstract}

Index Terms - In vitro propagation, BAP, NAA, synthetic seeds.

\section{INTRODUCTION}

Oxalis triangularis, commonly known as "False Shamrock", is an edible perennial plant belonging to the Oxalidaceae family. It is native to Brazil. Oxalis triangularis grow from bulbs, and their propagation is obtained by division of the bulbs. Like other bulbous plants, Oxalis triangularis goes through dormancy period on a regular basis. Somatic embryos and synthetic seeds (embryos or micro shoots encapsulated in artificial endosperms) hold great potential for large scale clonal propagation of superior genotypes of heterogeneous plants [1], [2]. They have also been used in commercial plant production and for the multiplication of parental genotypes in large scale hybrid seed production [3], [4].

In Malaysia despite popular demand, this species is usually imported from Thailand, hence there is a necessity to mass propagate this species. Nowadays, mass propagation by using tissue culture method is quite common, the current work reports and discusses the production of artificial seeds from micro shoots derived from stem explants of this species. The subsequent in vitro regeneration was also achieved at high rates and the regenerated plantlets were successfully acclimatized. The development of encapsulated

Manuscript received on March 5, 2013; revised May 6, 2013. This work was supported by University of Malaya Research Grants (RP025/2012A and PV025/2011B).

All the authors are with the Institute of Biological Sciences, Faculty of Science, University of Malaya, 50603 Kuala Lumpur, Malaysia (email: rosna@um.edu.my, fara_aid@siswa.um.edu.my, jam_sya@yahoo.com, noorlidah@um.edu.my, mohajer.ae@gmail.com). or synthetic seed technology brings up a new prospect in agriculture and floriculture industry. Production of synthetic seeds is effective and acts as an important alternative method of propagation in commercially important plants, which do not produce seeds. Plants could be produced in large scale with high volumes. Consequently, genetic uniformity and stability of the plants could be maintained. Due to the sterility, it could be easily transported and has potential for long term storage without losing viability. The aims of this paper are to produce artificial seeds and to investigate the ability of the synthetic seeds to regenerate after 7 and 30 days of storage at low temperature $\left(4 \pm 1^{\circ} \mathrm{C}\right)$.

\section{MATERIALS AND METHODS}

\section{A. Explant Sources and Encapsulation Matrix}

Micro shoots of Oxalis triangularis were induced from stem explants cultured on MS medium supplemented with $0.5 \mathrm{mg} / 1 \mathrm{NAA}$ and $0.5 \mathrm{mg} / 1 \mathrm{BAP}$. The stem cultures were maintained in the culture room at $25 \pm 1{ }^{\circ} \mathrm{C}$ for 16 hours light and 8 hours dark. Illumination was at 1000 lux and relative humidity was $90-100 \%$. The standard method for preparation of capsule matrix was followed [5].

B. Final Stage Preparation of 3\% $(w / v)$ Sodium Alginate Solution $\left(\mathrm{NaC}_{6} \mathrm{H}_{7} \mathrm{O}_{6}\right)$

To prepare $3 \%(\mathrm{w} / \mathrm{v})$ sodium alginate solution in $100 \mathrm{ml}$ MS basal medium without calcium chloride dehydrate $\left(\mathrm{CaCl}_{2} \cdot 2 \mathrm{H}_{2} \mathrm{O}\right), 1 \mathrm{~g}$ sodium alginate powder was dissolved gradually. Sucrose $(3.0 \mathrm{~g})$ and hormones $(1.0 \mathrm{mg} / 1 \mathrm{NAA}$ and $1.5 \mathrm{mg} / \mathrm{l} \mathrm{BAP}$ ) were added. Media $\mathrm{pH}$ was adjusted to 5.8 . This solution was autoclaved for 20 minutes at $121^{\circ} \mathrm{C}$ and $104 \mathrm{kpa}$.

\section{Preparation of Calcium Chloride Dehydrate Solution $\left(\mathrm{CaCl}_{2} \cdot 2 \mathrm{H}_{2} \mathrm{O}\right.$ )}

Calcium chloride dehydrate solution was used as a complexion agent. To prepare $75 \mathrm{mM} \mathrm{(w/v)} \mathrm{calcium}$ chloride dehydrate in $100 \mathrm{ml}$ distilled water, $1.47 \mathrm{~g}$ $\mathrm{CaCl}_{2} \cdot 2 \mathrm{H}_{2} \mathrm{O}$ was dissolved gradually. This solution was autoclaved for 20 minutes at $121^{\circ} \mathrm{C}$ and $104 \mathrm{kpa}$.

\section{Encapsulation Techniques and Bead Formation}

They were then, being dropped one by one in the $\mathrm{CaCl}_{2} \cdot 2 \mathrm{H}_{2} \mathrm{O}$ solution. The micro shoots were allowed to get encapsulated (hardened) by allowing them to remain in $\mathrm{CaCl}_{2} \cdot 2 \mathrm{H}_{2} \mathrm{O}$ solution for 30 minutes. These beads were taken out and transferred into sterile distilled water to wash out the excess $\mathrm{CaCl}_{2} \cdot 2 \mathrm{H}_{2} \mathrm{O}$ solution and were blotted with sterile tissue paper. 


\section{E. Low Temperature Storage}

Sterile encapsulated beads of Oxalis triangularis were stored under dark condition at low temperature $\left(4 \pm 1^{\circ} \mathrm{C}\right)$. The survival rates for germination after 7 and 30 days were recorded. Thirty replicates were used in each treatment.

\section{F. Data Analysis}

All experiments were conducted using a completely randomized design. Data collected were statistically analyzed using Duncan's Multiple Range Test (DMRT). Mean with different letters in the same column differ significantly at $\mathrm{p}<0.05$.

\section{RESULtS}

Synthetic seeds were created by encapsulation of micro shoots of $O$. triangularis in sodium alginate solution (Fig. 1a). The micro shoots were derived from stem explants of this species after being cultured for one month on MS medium supplemented with $0.5 \mathrm{mg} / 1 \mathrm{NAA}$ and $0.5 \mathrm{mg} / \mathrm{l}$ BAP. Table 1 shows the germination of synthetic seeds on MS basal media after 0,7 and 30 days of storage. Even after 30 days of storage, the artificial seeds retained the ability to germinate and gave high regeneration rate $(90 \%)$ and the percentage of survival rate was also high (77-86\%) as compared to control. Mean number of shoots formed was the highest after 7 days of storage. Root formation was observed in all treatments.

TABLE I: GERMINATION OF SYNTHETIC SEEDS OF OXALIS TRIANGULARIS AFTER BEING STORED AT DIFFERENT DURATIONS

\begin{tabular}{ccccc}
\hline \hline $\begin{array}{c}\text { Storage } \\
\text { duration } \\
\text { (Days) }\end{array}$ & $\begin{array}{c}\text { Conversion } \\
\text { frequency } \\
(\%)\end{array}$ & $\begin{array}{c}\text { Percentage } \\
\text { of survival } \\
(\%)\end{array}$ & $\begin{array}{c}\text { No. of shoots } \\
\text { (Mean } \pm \text { SE) }\end{array}$ & $\begin{array}{c}\text { Root } \\
\text { formation }(\%)\end{array}$ \\
\hline $\begin{array}{c}\text { (control) } \\
7\end{array}$ & 60.00 & 66.67 & $2.10 \pm 0.6 \mathrm{a}$ & $100.00 \pm 0.0 \mathrm{a}$ \\
\hline 30 & 96.67 & 86.21 & $4.57 \pm 0.7 \mathrm{~b}$ & $100.00 \pm 0.0 \mathrm{a}$ \\
\hline \hline
\end{tabular}

Each value represents the mean $\pm \mathrm{SE}$ of 30 replicates. The mean with

different letters in the same column differ significantly at 0.05 level.

TABLE II: SYNTHETIC SEEDS GERMINATION OF OXALIS TRIANGULARIS IN DIFFERENT SOWING SUBSTRATES

\begin{tabular}{|c|c|c|}
\hline $\begin{array}{l}\text { Sowing } \\
\text { substrate }\end{array}$ & Treatment & Observation \\
\hline $\begin{array}{l}\text { MS basal } \\
\text { medium }\end{array}$ & Without hormone & $\begin{array}{l}\text { Encapsulated beads regenerated into } \\
\text { complete plantlets. }\end{array}$ \\
\hline \multirow{2}{*}{$\begin{array}{l}\text { Black } \\
\text { soil } \\
\text { (non } \\
\text { sterile) }\end{array}$} & $\begin{array}{l}\text { Moistened with } \\
\text { distilled water }\end{array}$ & $\begin{array}{c}\text { Encapsulated beads started to shrink } \\
\text { after a few days and eventually } \\
\text { contaminated. }\end{array}$ \\
\hline & $\begin{array}{l}\text { Moistened with liquid } \\
\text { MS without sucrose }\end{array}$ & $\begin{array}{l}\text { All encapsulated beads were } \\
\text { contaminated with fungal infection. }\end{array}$ \\
\hline \multirow{2}{*}{$\begin{array}{c}\text { Black } \\
\text { soil } \\
\text { (sterile) }\end{array}$} & $\begin{array}{l}\text { Moistened with } \\
\text { distilled water }\end{array}$ & $\begin{array}{l}\text { Encapsulated beads showed no } \\
\text { response and ultimately shrink. }\end{array}$ \\
\hline & $\begin{array}{l}\text { Moistened with liquid } \\
\text { MS without sucrose }\end{array}$ & $\begin{array}{l}\text { All encapsulated beads were } \\
\text { contaminated with fungal infection. }\end{array}$ \\
\hline
\end{tabular}

Each medium was represented by 20 replicates.

Interestingly, synthetic seeds that were stored prior to being cultured showed significantly higher conversion frequency than synthetic seeds directly sowed on MS basal media (control). Higher percentage of survival was also recorded when the synthetic seeds were stored prior to being cultured on MS basal media compared to the control. It was also observed that storage period of 7 days was most optimum to ensure a high plantlet conversion rate and survival percentage. Shooting was also the highest from synthetic seeds stored for 7 days. This was clearly demonstrated in Table I.

Table II indicates various media or substrates tested for germination of the synthetic seeds. The optimum substrate was MS basal medium (Fig. 1b and Fig. 2). After four weeks, the micro shoots elongated and eventually undergo complete regeneration. Other sowing substrates were shown to produce poorer results when compared to MS basal media. Substrates moistened with only distilled water resulted in shrinking of the synthetic seeds, while substrates moistened with liquid MS without sucrose resulted in fungal contamination. Finally the plantlets regenerated from synthetic seeds sowed on MS basal media were successfully acclimatized in the garden.

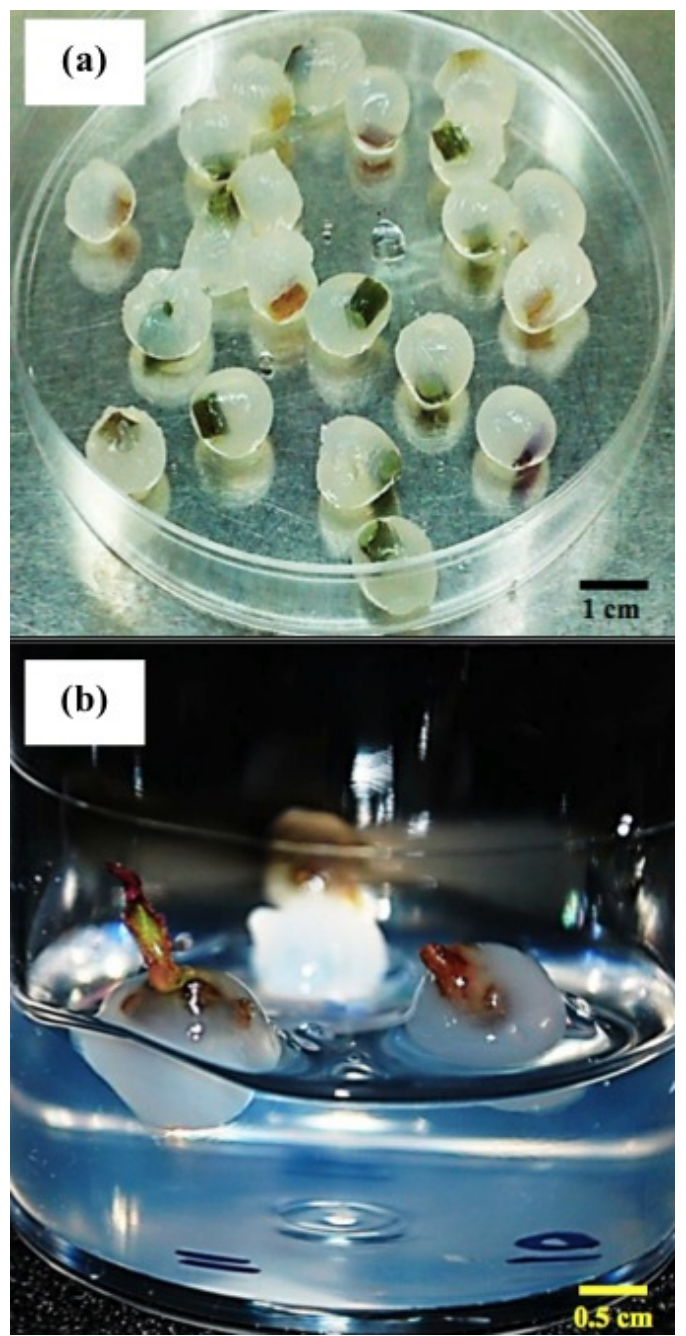

Fig. 1. (a) Encapsulated beads of Oxalis triangularis before being stored at low temperature $\left(4^{\circ} \mathrm{C} \pm 1{ }^{\circ} \mathrm{C}\right)$, (b) Shoots emerged from the encapsulated micro shoots of Oxalis triangularis after 7 days being cultured on MS basal medium.

\section{DISCUSSION}

Creation and production of artificial seeds have been reported in many species [5], [6] - [9]. From Tables I and II, the observations after 7 days of encapsulated beads being germinated on the substrates both in black soil and sterile black soil gave negative results which failed to survive and finally the synthetic seeds died. On black soil substrate moistened with distilled water, the encapsulated beads during the first 7 days already showed shrinking sign where 
they failed to germinate and eventually contaminated with fungal infection. While synthetic seeds of Oxalis triangularis which were sown on sterile black soil moistened with distilled water did not show any sign of contamination, no germination response was observed. However, the beads eventually shrunk. Both synthetic seeds of Oxalis triangularis sown in black soil and sterile black soil moistened with liquid MS without sucrose gave similar observations whereby, all encapsulated beads were contaminated with fungal infection after seven days.
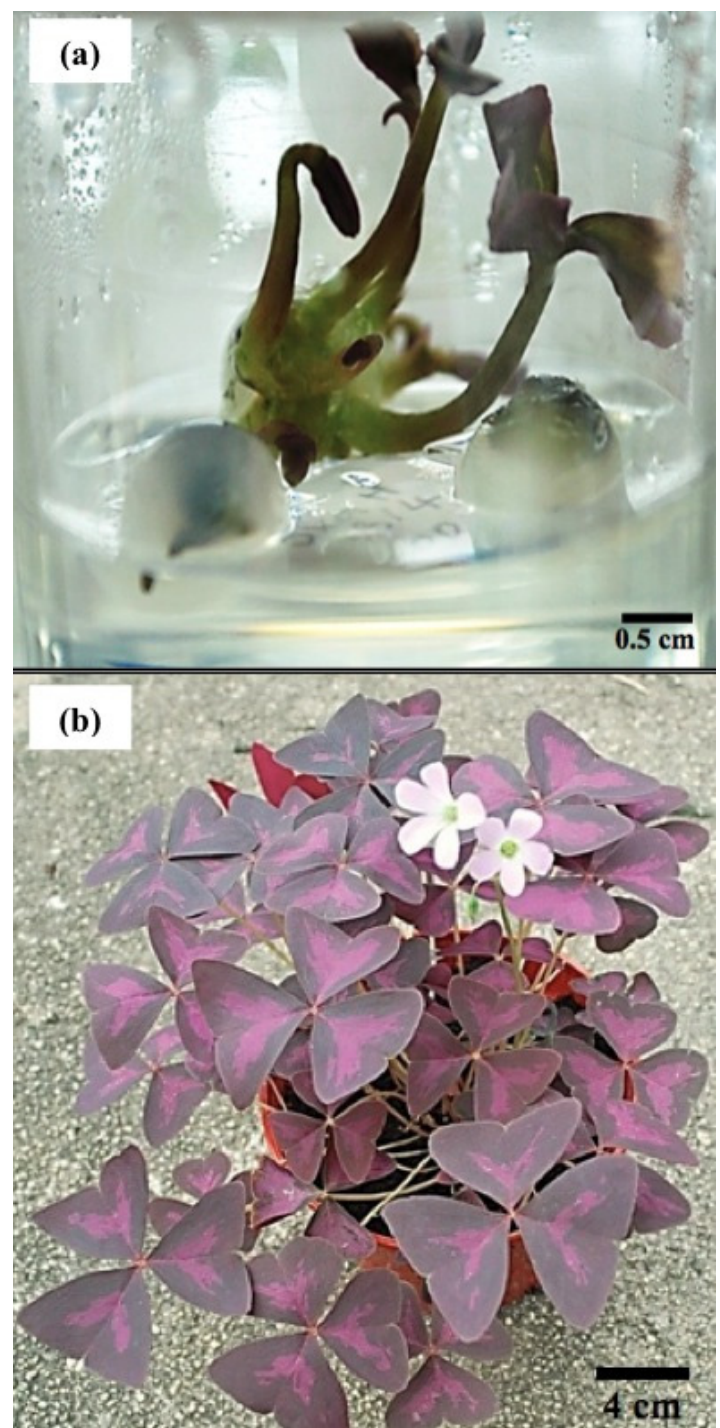

Fig. 2. (a) Development of micro shoots of Oxalis triangularis from synthetic seeds after 4 weeks being cultured on MS basal medium, (b) Regenerated plantlet of $O$. triangularis after successful acclimatization.

Further studies were also carried out to compare synthetic seeds of Oxalis triangularis sown directly on MS basal medium, black soil and sterile black soil (Table II). The results showed that conversion frequency of synthetic seeds of Oxalis triangularis into complete plantlets were better under in vitro conditions compared to in vivo conditions. Synthetic seeds of Oxalis triangularis have the capability to respond when cultured on MS basal medium resulted in a high rate of plantlets regeneration. More than $60 \%$ successful regeneration from synthetic seeds of Oxalis triangularis was observed (Table II). Successful plant regeneration from synthetic seeds of Oxalis triangularis on MS basal medium was probably because the beads were cultured under aseptic conditions. Therefore, probability for the beads to get contaminated was much lower compared to seeds directly sown on in vivo substrates.

The potential of synthetic seeds to be sown directly on in vivo substrates has received limited attention. From previous studies, Preece and West [10] were successful in sowing Hibiscus moscheutos directly into a greenhouse hydroponic system, both with and without light pretreatment. Bapat and Rao [11] conducted research on in vivo growth of encapsulated axillary buds of mulberry (Morusindica L.) and reported that addition of a fungicide to the alginate beads prevented contamination of the bud and increased survival of the buds when sown in soil. Ramakrishnappa [12] also observed that addition of fungicide $(0.1 \%$ carbendazim) and bacteriocide $(0.1 \%$ streptomycin $)$ into the encapsulating gel reduced the incidence of fungal and bacterial contamination to a minimum level and nearly $95 \%$ of the beads remained healthy. Researches need to be done to improve germination percentage of synthetic seeds when directly sown on non-sterile environment, such as in greenhouse or directly in the field. The present study proved that artificial seeds and tissue culture methods can be useful for plant multiplication and conservation.

\section{CONCLUSION}

In the present study, production of synthetic seeds was attempted from this species and the synthetic seeds managed to survive after 7 and 30 days after storage at $4{ }^{\circ} \mathrm{C}$. The rate of synthetic seeds conversion to complete plants after 7 days was $96.67 \%$ with 4.57 mean shoot numbers, while after 30 days of storage, the conversion rate slightly decreased to $90 \%$ with only 3.97 shoots formation per bead.

\section{ACKNOWLEDGMENT}

The authors would like to thank University of Malaya, Kuala Lumpur, Malaysia, for the Research Grant RP025/2012A and Postgraduate Research Grant PV025/2011B.

\section{REFERENCES}

[1] K. Redenbaugh, J. A. Fujii, and D. Slade, "Hydrated coatings for synthetic seeds. In: Redenbaugh, K. (ed)," Synseeds Application of Synthetic Seeds to Crop Improvement, CRC Press, Boca Raton, pp. 35-45, 1993.

[2] K. Mamiya and Y. Sakamoto, "A method to produce encapsulatable units for synthetic seeds in Asparagus officinalis," Plant Cell Tissue Organ Culture, vol. 64, pp. 27-32, 2001.

[3] Y. P. S. Bajaj, "Somatic embryogenesis and synthetic seed," Biotechnology in Agriculture and Forestry, vol. 30, pp. 1-472, Springer-Verlag. Berlin, 1995.

[4] D. R. Cyr, "Seed substitutes from the laboratory, In: Black, M. and Bewley, J. D. (Eds.)," Seed Technology and its Biological Basis, Sheffield Acad, Press, Sheffield, pp. 326-372, 2000.

[5] R. M. Taha, A. Saleh, N. Mahmad, N. A. Hasbullah, and S. Mohajer, "Germination and plantlet regeneration of encapsulated microshoots of aromatic rice (Oryza sativa L. Cv. MRQ 74)," The Scientific World Journal, vol. 2012, Article ID 578020, 6 pages, 2012. doi: $10.1100 / 2012 / 578020$

[6] P. K. Siong, S. Mohajer, and R. M. Taha, "Production of artificial seeds derived from encapsulated in vitro micro shoots of cauliflower, Brassica oleracea var. botrytis," Romanian Biotechnological Letters, vol. 17, pp. 7549-7556, 2012.

[7] R. M. Taha, N. Daud, N. A. Hasbullah, and A. Awal, "Somatic embryogenesis and production of artificial seeds in Saintpaulia ionantha Wendle. International Symposium on in vitro culture and 
horticultural breeding," Acta horticulturae, vol. 829, pp. 331-336, 2009 .

[8] R. M. Taha, N. A. Hasbullah, and A. Awal, "Production of synthetic seeds from micro shoots and somatic embryos of Gerbera jamesonii Bolus ex. Hook f. International Symposium on in vitro culture and horticultural breeding," Acta Horticulturae, vol. 829, pp. 91-98, $2009 \mathrm{~b}$.

[9] P. T. Lynch, Plant Cryopreservation Workshop, University of Malaya, Kuala Lumpur, Malaysia, 3-5 September 2002.

[10] J. E. Preece and T. P. West, "Greenhouse growth and acclimatization of encapsulated Hibiscus moscheutos nodal segments," Plant Cell Tissue Organ Culture, vol. 87, pp. 127-138, 2006.

[11] V. A. Bapat and P. S. Rao, "In vitro growth of encapsulated axillary buds of mulberry (MorusindicaL.)," Plant Cell Tissue Organ Culture, vol. 20, pp. 69-70, 1990.

[12] Ramakrishnappa, "Studies on somatic embryogenesis and production of synthetic seeds in Gladiolus cultivars," Ph. D. Thesis, University of Agricultural Sciences, Bangalore, 1998.

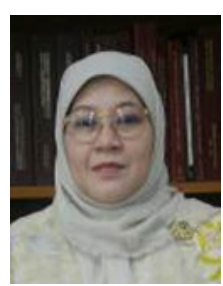

Rosna Mat Taha was born in Malaysia on January 22, 1958. In 1984, she obtained her B.Sc. in Botany from University of Malaya, Kuala Lumpur, Malaysia and eventually completed her Ph.D in 1989 on Plant Morphogenesis from University of Wales, Cardiff, UK.

She is currently working as a lecturer (professor) at Institute of Biological Sciences, Faculty of Science, University of Malaya, Kuala Lumpur, Malaysia. She has published more than 100 papers in ISI-cited journals, proceedings, book chapters and etc.

Prof. Taha is also an expert in plant tissue culture, morphogenesis, biotechnology, pigment and cellular behavior studies. She has won many awards (more than 20) in her research. She is a member of European Association for Reserach on Plant Breeding (EUCARPIA) and International Society for Horticultural Science (ISHS). Also, she is the associate editor of Asian Journal of Biotechnology, Asian Journal of Plant Sciences and Journal of Applied Sciences.

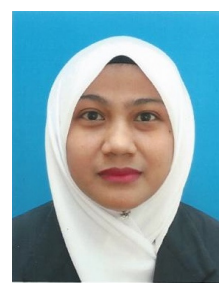

Noraini Mahmad was born in Kelantan, Malaysia on January 24, 1977. She obtained her B.Sc (Biotechnology) in 2000 from University of Malaya, Malaysia. Eventually in 2012, she obtained her M.Sc (Biotechnology) from University of Malaya, Malaysia She is currently pursuing her Ph.D also at Institute of Biological Sciences, Faculty of Science, University of Malaya, Kuala Lumpur, Malaysia.

To date, she had authored 2 scientific articles published in ISI-cited journals. She also had participated in several conferences such as $1^{\text {st }}$ International Symposium on Sustainable Vegetable Production in South East Asia (2011).

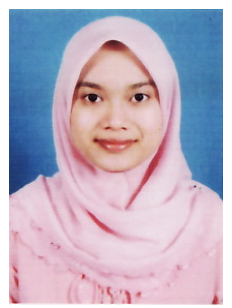

Jamilah Syafawati Yaacob had obtained her B.Sc (Biotechnology \& Biochemistry and Molecular Biology) in 2007 from University of Melbourne, Australia and eventually her M.Sc (Crop Biotechnology) in 2009 from the University of Nottingham Malaysia Campus. She had completed her Ph.D in early 2013 on Plant/Crop Biotechnology from University of Malaya, Malaysia.

Upon completing her Ph.D, she is currently serving University of Malaya as a senior lecturer at the Institute of Biological Sciences, Faculty of Science, University of Malaya, Kuala Lumpur, Malaysia. To date, she had published 10 articles in reputable ISI-cited journals and proceedings. She also had participated and won awards in various conferences and exhibitions related to her work.

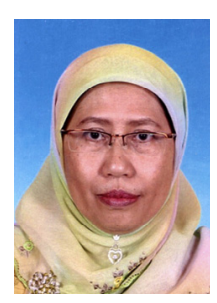

Noorlidah Abdullah had graduated in B.Sc (Medical Biochemistry) in 1984 from University of Surrey, United Kingdom, M.Sc (Mycology) in 1989 and Ph.D (Applied Mycology) in 1997 both from University of Malaya, Malaysia.

She has contributed substantially to research, teaching and administration since she joined the Institute of Biological Sciences in 1997. Later she was promoted to Associate Professor in Oct 2002 and then professor in 2008 and has become well known for her research in Fungal Biotechnology and Food Mycology.

She was given due recognition for her expertise in food mycology (mycotoxins) by the Ministry of Health for whom she has been an expert committee in Asean Expert Group On Food Safety and Food Additives and Contaminants Committee. She has published 70 articles in reputable journals and has supervised 48 postgraduate students.

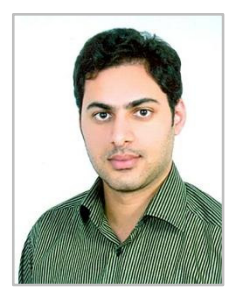

Sadegh Mohajer had obtained his M.Sc (Plant Breeding) in 2008 from Azad University, Iran and currently pursuing his Ph.D in Plant Biotechnology at Institute of Biological Sciences, Faculty of Science, University of Malaya, Kuala Lumpur, Malaysia. His $\mathrm{Ph} . \mathrm{D}$ is currently being sponsored by the university under the Bright Sparks scholarship.

Prior to joining the University of Malaya, Malaysia, he had worked as a research scientist at IranLevasanat Agricultural Extension Center until 2010 and had also given lectures for Experimental Design Course at Payamnur University (2009-2010). To date, he had authored over 12 articles, edited 1 book and 2 book chapters. He also had taken part in more than 5 international conferences and won several awards, such as the best science expert at Iran-Shemiranat Agricultural Organization in 2010. He was also ranked first in Iran Plant Breeding M.Sc entrance examination in 2006.

Furthermore, he was also among the editorial board members of Journal of Sciencia and had evaluated scientific articles for African Journal of Biotechnology and Scientia Horticulturae. 